\title{
Development and validation of a novel PCR- RFLP based method for the detection of 3 primary mitochondrial mutations in Leber's hereditary optic neuropathy patients
}

Siobhan Eustace Ryan ${ }^{1 *}$, Fergus Ryan ${ }^{2}$, David Barton ${ }^{3}$, Veronica O'Dwyer ${ }^{1}$ and Derek Neylan ${ }^{2}$

\begin{abstract}
Background: Leber's Hereditary Optic Neuropathy (LHON; MIM 535000) is one of the most commonly inherited optic neuropathies and it results in significant visual morbidity among young adults with a peak age of onset between the ages of 15-30. The worldwide incidence of LHON is approximately 1 in 31,000. $95 \%$ of LHON patients will have one of 3 primary mitochondrial mutations, G3460A (A52T of ND1), G11778A (R340H of ND4) and T14484C (M64V of ND6). There is incomplete penetrance and a marked gender bias in the development of visual morbidity with approximately $50 \%$ of male carriers and $10 \%$ of female carriers developing optic neuropathy. Visual recovery can occur but is dependent on the mutation present with the highest level of visual recovery seen in patients who have the T14484C mutation. The 3 primary mutations are typically identified by individual end-point PCR-restriction fragment length polymorphism (RFLP) or individual targeted bi-directional Sanger sequencing reactions. The purpose of this study was to design a simple multiplex PCR-RFLP that could detect these 3 primary LHON mutations in one assay.

Methods: PCR primers were designed to incorporate a Maell restriction site in the presence of 3460A and 14484C mutations with the 11778A mutation naturally incorporating a Maell site. A multiplex PCR-RFLP assay was developed to detect the 3 common mutations in a single assay. Synthetic LHON controls based on the mitochondrial genome harbouring the 3 common mutations were synthesized and cloned into plasmids to act as reliable assay controls. DNA from previously tested patients and the synthetic LHON controls were subjected to the multiplex PCR-RFLP assay. The RFLP products were detected by agarose gel electrophoresis.
\end{abstract}

Results: The novel PCR-RFLP assay accurately detects the 3 primary mutations both in patient DNA and in synthesized DNA control samples with a simple visual mutation detection procedure. The synthesized DNA was demonstrated to be a robust control for the detection of LHON Mutations.

Conclusion: In this paper, we describe a novel, robust and simple PCR-RFLP based method for the detection of mutations causing LHON, and report the generation of a series of LHON DNA controls suitable for all currently published assays.

Keywords: LHON, Mitochondrial mutations, Mutation detection, Visual morbidity, Multiplex PCR

\footnotetext{
* Correspondence: siobhan.eustace@dit.ie

${ }^{1}$ National Optometry Centre, Dublin Institute of Technology, Kevin Street,

Dublin 8, Ireland

Full list of author information is available at the end of the article
}

\section{Biomed Central}

(c) 2015 Eustace Ryan et al. Open Access This article is distributed under the terms of the Creative Commons Attribution 4.0 International License (http://creativecommons.org/licenses/by/4.0/), which permits unrestricted use, distribution, and reproduction in any medium, provided you give appropriate credit to the original author(s) and the source, provide a link to the Creative Commons license, and indicate if changes were made. The Creative Commons Public Domain Dedication waiver (http://creativecommons.org/publicdomain/zero/1.0/) applies to the data made available in this article, unless otherwise stated. 


\section{Background}

Leber's hereditary optic neuropathy (LHON; MIM 535000) is one of the most commonly inherited optic neuropathies and it results in significant visual morbidity among young adults $[1,2]$. The disorder is the result of mitochondrial dysfunction wherein primary mitochondrial DNA (mtDNA) mutations affect complex I subunits of the respiratory chain [3]. LHON is the most common among primary mitochondrial diseases with a prevalence of 1 in 31,000 in the North of England, 1 in 39,000 in the Netherlands and 1 in 50,000 in Finland [4-6]. In some countries, approximately $95 \%$ of individuals with LHON have one of 3 primary mtDNA mutations; G3460A (A52T of ND1), G11778A (R340H of ND4) and T14484C (M64V of ND6) $[3,7,8]$ while other rare mutations (such as G13730A, G14459A, C14482G, A14495G, C14498T, C14568Tand T14596A) account for the final $5 \%$ [9-16]. LHON demonstrates marked gender bias and an incomplete penetrance, with approximately $50 \%$ of males and $10 \%$ of females who harbour one of the above mutations actually developing optic neuropathy [17-19]. This indicates that environmental or other genetic factors must play a role in penetrance. Alcohol consumption, smoking, certain prescription medications, stress and critical illness have been implicated in the onset of symptoms in LHON mutation carriers [17, 18, 20, 21].

The peak age of LHON onset is between 15-30 years and $95 \%$ of carriers who will experience visual failure will do so before the age of 50 years [22]. However, visual deterioration can occur any time during the first to the seventh decade of life [23]. Clinically, there tends to be an acute loss of vision in one eye generally followed by loss of vision in the other eye within 8 weeks. In the majority of cases, LHON pathology is limited to a highly specialized group of cells within the eye known as retinal ganglion cells (RGCs). Histological analysis of the optic nerve in LHON patients reveals minimal evidence of any inflammation, but shows general axonal depletion centrally and fibrocytic scarring. Any residual axons were limited to superior and temporal peripheral clusters [24].

Visual recovery can occur in some LHON patients, but the extent of which is influenced by the kind of mutation involved in the development of a particular patient's LHON. The highest level of visual recovery is seen with patients who have the T14484C mutation (up to $58 \%$ ), followed by those with the G3460A mutation (up to $25 \%$ ). Patients who harbour the G11778A mutation have the lowest level of visual recovery [25-28]. Thus, an accurate mutation detection strategy can have a significant prognostic value to the $\mathrm{LHON}$ patient.

Current diagnostic strategies for the 3 most common mutations causing LHON include individual endpoint PCR-RFLP [29], allele specific PCR [30], real time PCR [31] and PCR followed by Sanger / pyrosequencing [32]. In this study, we successfully designed a simple multiplex PCRRFLP to detect the 3 primary mitochondrial LHON mutations and also describe the synthesis of a series of LHON control sequences that act as a robust and patient-free resource for LHON test controls and assay development.

\section{Methods}

\section{Patient DNA}

Patient DNAs were obtained from the Centre for Medical Genetics, Our Lady's Hospital for Sick Children, Dublin, Ireland and Oxford Medical Genetics Laboratories, Oxford, UK. DNA was extracted from peripheral blood using the Centra Puregene Blood Kit (Qiagen, Manchester, UK) or the EZ1 Blood Kit on the EZ1 advanced XL instrument (Qiagen, Manchester, UK) according to the manufacturers' instructions. All samples used in this study were previously tested for LHON mutations using PCR amplification and DNA sequencing. To maintain patient confidentiality during this study, aliquots of residual DNA material from the diagnostic test were labelled with the LHON mutation detected and irreversibly anonymised. The use of patient DNA in this study has received ethical approval from the Dublin Institute of Technology Research Ethics Committee (RN: 14-06).

\section{Synthetic control DNA}

To provide an unlimited, reliable and patient-free resource for LHON testing across all current testing platforms as well as to allow for the development of the multiplex PCR-restriction fragment length polymorphism (RFLP) test described in this study, LHON control sequences were synthesised and cloned into standard plasmids by Eurofins Genomics (London, UK) or Life Technologies (Carlsbad, USA) based on the reference sequence NC_012920.1. A total of 6 plasmids were generated containing the 3460G, 3460A, 11778G, 11778A, $14484 \mathrm{~T}$ and $14484 \mathrm{C}$ sequences. The 3460 plasmids contained mitochondrial sequences from 3275 to 4272 , the 11778 plasmids contained mitochondrial sequences from 11580 to 12118 and the 14484 plasmids contained mitochondrial sequences from 14449 to 15022 (Table 1). For the generation of synthetic diagnostic controls, the plasmids were combined at a concentration of $1.5 \mathrm{ng} / \mu \mathrm{l}$ to generate mixes containing none or one of the primary LHON mutations as follows; Normal control that contained no LHON mutations (a mix of 3460G, 11778G and $14484 \mathrm{~T}$ plasmids at a concentration of $1.5 \mathrm{ng} / \mu \mathrm{l}$ ), $3460 \mathrm{~A}$ control that contained 3460A, 11778G and $14484 \mathrm{~T}$ plasmids, $11778 \mathrm{~A}$ control that contained 3460G, 11778A, 14484 T plasmids, and 14484C control that contained 3460G, 11778G, 14484C plasmids. This information is summarised in Table 1. 
Table 1 Synthetic LHON control plasmids and mixes

\begin{tabular}{|c|c|c|c|c|c|}
\hline Plasmid & Nucleotide Positions & Normal Mix & $3460 \mathrm{~A}$ mix & 11778A mix & $14484 C$ mix \\
\hline $3460 \mathrm{G}(\mathrm{N})$ & $3275-4272$ & $x$ & & $x$ & $x$ \\
\hline $3460 A(M)$ & $3275-4272$ & & $x$ & & \\
\hline $11778 \mathrm{G}(\mathrm{N})$ & $11580-12118$ & $x$ & $x$ & & $x$ \\
\hline $11778 \mathrm{~A}(\mathrm{M})$ & $11580-12118$ & & & $x$ & \\
\hline $14484 \mathrm{~T}(\mathrm{~N})$ & $14449-15022$ & $x$ & $x$ & $x$ & \\
\hline $14484 C(M)$ & $14449-15022$ & & & & $x$ \\
\hline
\end{tabular}

\section{Primer design and PCR}

Primers (Sigma Genosys, Arklow, Ireland) for the multiplex PCR-RFLP (Table 2) were designed to incorporate a MaeIII (Roche, Burgess Hill, UK, Catalogue Number $10822230001)$ restriction site ( $\downarrow$ GTnAC) in the presence of $3460 \mathrm{~A}$ and $14484 \mathrm{C}$ mutations. MaeIII was chosen because the 11778 mutation naturally introduces a MaeIII restriction site and minor alterations of the PCR primers as shown in Fig. 2a and Table 2, the 3460A and 14484C mutations also introduce a MaeIII site to allow the development of a multiplex PCR and RFLP strategy based on the modified primers and MaelII restriction enzyme. The sequences of the PCR products highlighting the positions of the oligonucleotice primers and the MaeIII restriction sites are shown in the Additional files 1,2 and 3. In Fig. 2a, alterations in the primer sequences leading to the generation of a MaeIII site are shown in lower case. Additionally, the 3460 PCR product contains a naturally occurring MaeIII site at position 3736 to act as an internal control of complete restriction in the assay. This multiplex assay uses one PCR reaction and one restriction enzyme thus allowing for a simple and cost effective assay for the 3 common LHON associated mutations. The primers produce products as follows: $3460 \mathrm{~F} / \mathrm{R}$ (333 bp), $11778 \mathrm{~F} / \mathrm{R}$ (164 bp) and 14484 F/R (236 bp), respectively. In the presence of the mutated allele, the products change as follows: the $3460 \mathrm{~A}$ mutation resulting in $279 \mathrm{bp}, 28 \mathrm{bp}$ and $26 \mathrm{bp}$ (control of restriction), $11778 \mathrm{~A}$ mutation producing $135 \mathrm{bp}, 29 \mathrm{bp}$, and $14484 \mathrm{C}$ mutation producing $205 \mathrm{bp}, 31 \mathrm{bp}$, respectively. PCR was performed in a reaction containing $50 \mathrm{ng}$ of genomic DNA (or $1 \mu \mathrm{l}$ of the synthetic control described above) using 1 unit of Platinum Taq polymerase (Life
Technologies, Carlsbad, USA, Catalogue Number 10966-034), $100 \mu \mathrm{M}$ dNTP (Life Technologies, Carlsbad, USA, Catalogue Number 10297-018), a primer mix containing $250 \mathrm{ng}$ of $3460 \mathrm{~F} / \mathrm{R}, 60 \mathrm{ng}$ of $11778 \mathrm{~F} / \mathrm{R}$ and $40 \mathrm{ng}$ of $14484 \mathrm{~F} / \mathrm{R}$ and standard PCR buffer containing $3.5 \mathrm{mM} \mathrm{MgCl}_{2}$ (Life Technologies, Carlsbad, USA, Catalogue Number 10966-034). PCR conditions were $95{ }^{\circ} \mathrm{C}$ for $5 \mathrm{~min}$ followed by 35 cycles of $95^{\circ} \mathrm{C}$ for $30 \mathrm{~s}, 59^{\circ} \mathrm{C}$ for $30 \mathrm{~s}$ and $72{ }^{\circ} \mathrm{C}$ for $30 \mathrm{~s}$ followed by a final extension at $72{ }^{\circ} \mathrm{C}$ for $5 \mathrm{~min}$. Restriction with MaeIII was performed using a reaction containing $12 \mu \mathrm{l}$ of PCR product, $12.5 \mu \mathrm{l}$ of $2 \mathrm{X}$ MaeIII buffer and $0.5 \mu \mathrm{l}$ (1 unit) of MaeIII for a minimum of $2 \mathrm{~h}$ at $55{ }^{\circ} \mathrm{C}$. Restriction products were detected by electrophoresis on a $2.5 \%$ agarose gel (Life Technologies, Carlsbad, USA, Catalogue Number 16500100) containing $0.5 \mu \mathrm{g} / \mathrm{ml}$ ethidium bromide (Sigma Genosys, Arklow, Ireland, Catalogue Number E7637).

\section{Results}

The workflow and expected results are presented schematically in Fig. 1. As seen in Fig. 1, three PCR products are generated in the multiplex reaction with sizes of $333 \mathrm{bp}, 164 \mathrm{bp}$ and $236 \mathrm{bp}$ for the 3460, 11778 and 14484 products, respectively. Figure $1 \mathrm{~b}$ demonstrates the sizes of the restriction products generated from nonmutated samples and the sizes of restriction products generated from 3460, 11778 and 14484 mutated samples. Figure 1c depicts schematically the expected results from a diagnostic test on an agarose gel.

A range of patient DNA samples, non-mutated patient DNA samples, and synthetic control samples were tested in one assay using the multiplex PCR-RFLP as described above. The sizes of restriction products expected are

Table 2 Primer sequences for multiplex PCR-RFLP

\begin{tabular}{llll}
\hline Mutation & Forward Primer & Reverse Primer & Product Size \\
\hline G3460A & 5'-CCCCTACGGGCTACTACAACCCTTCGCTGtC & 5'-GATAGTAGAATGATGGCTAG & 333 bp \\
G11778A & 5'-AGCAAACTCAAACTACGAACG & 5'-TTACTAGCACAGAGAGTCTC & 164 bp \\
T14484C & 5'-AATAGCCATCGCTGTAGTATATCCAAAGACAgtCA & 5'-GTGCGAGAATAATGATGTATGC & 236 bp \\
\hline
\end{tabular}




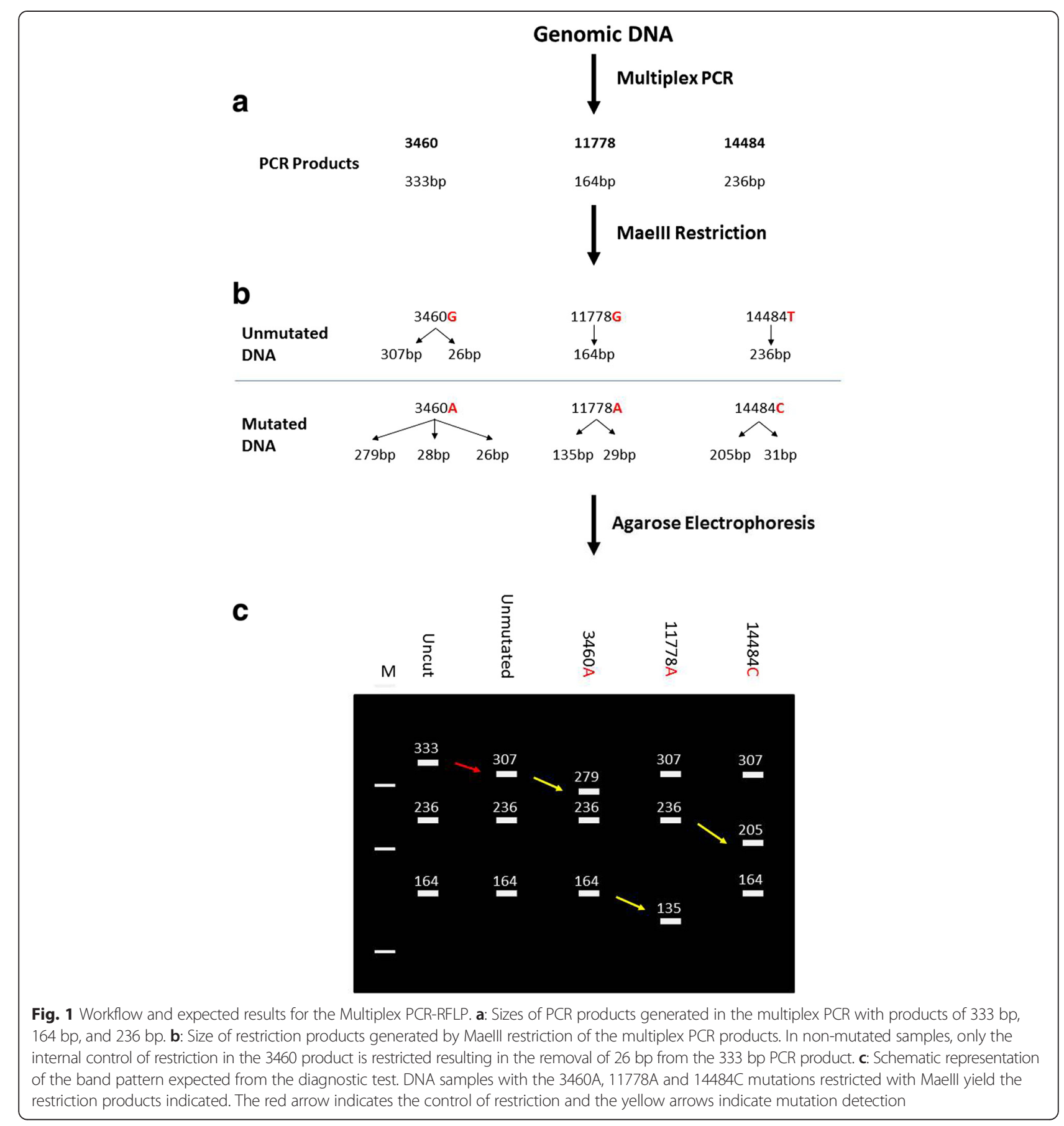

indicated in Table 3 and Fig. 1. The results of this analysis are presented in Fig. 2b. All patient DNA and synthetic controls were genotyped by a blinded researcher and were correctly genotyped using the assay. The naturally occurring MaeIII site in the 3460 PCR product is used as an internal control of restriction and removes $26 \mathrm{bp}$ from the PCR product. This can be seen between the uncut PCR product and the normal sample (lanes 2 and 3 ) and demonstrates a complete restriction in all lanes. The removal of the $26 \mathrm{bp}$ from the 3460 PCR product confirms complete restriction by MaeIII and assures accurate mutation detection. The mutations are detected by the MaeIII restriction with the removal of $28 \mathrm{bp}, 29 \mathrm{bp}$ and $31 \mathrm{bp}$ from the 3460, 11778 and 14484 PCR products, respectively. In all cases, the identification of the presence of a mutation is easily visualised on the $2.5 \%$ agarose gel (Fig. 2b). The patient controls and synthetic control samples behave identically indicating that the synthesized DNA controls are a viable alternative to patient DNA for controls. 
Table 3 PCR product and restriction product sizes expected in diagnostic test

\begin{tabular}{lllll}
\hline 1 & 2 & 3 & 4 & 5 \\
\hline Uncut PCR products & Maell Non-mutated & Maell 3460A & Maelll 11778A & Maell 14484C \\
333 & 307 & 279 & 307 & 307 \\
236 & 236 & 236 & 236 & 205 \\
164 & 164 & 164 & 135 & 164 \\
& & 28 & 29 & 31 \\
& 26 & 26 & 26 & 26 \\
\hline
\end{tabular}

Column 1: PCR product sizes (bp) generated in the multiplex PCR. Column 2: Size of Maelll restriction products obtained from non-mutated DNA samples. Column 3: Size of Maelll restriction products obtained from 3460A samples. Column 4: Size of Maelll restriction products obtained from 11778A samples. Column 5: Size of Maelll restriction products obtained from $14484 \mathrm{C}$ samples

As heteroplasmy is common with mitochondrial mutations, a mutation detection strategy must be capable of detecting heteroplasmy. Figure 3 presents an assay on heteroplasmic 11778 samples with approximately $90 \% 11778 \mathrm{~A}$ and approximately $90 \% 11778 \mathrm{G}$, indicating that the assay can accurately detect the presence of heteroplasmy to a level of approximately $10 \%$. Complete restriction of the naturally occurring MaeIII site in the 3460 PCR product again assures that the restriction is complete and that heteroplasmy was accurately detected.

\section{Discussion}

This study aimed to develop a novel PCR-RFLP based multiplex assay for the detection of the 3 common primary mutations leading to Leber hereditary optic neuropathy (LHON). Approximately $95 \%$ of LHON patients will have one of these 3 mutations, G3460A (13\%),

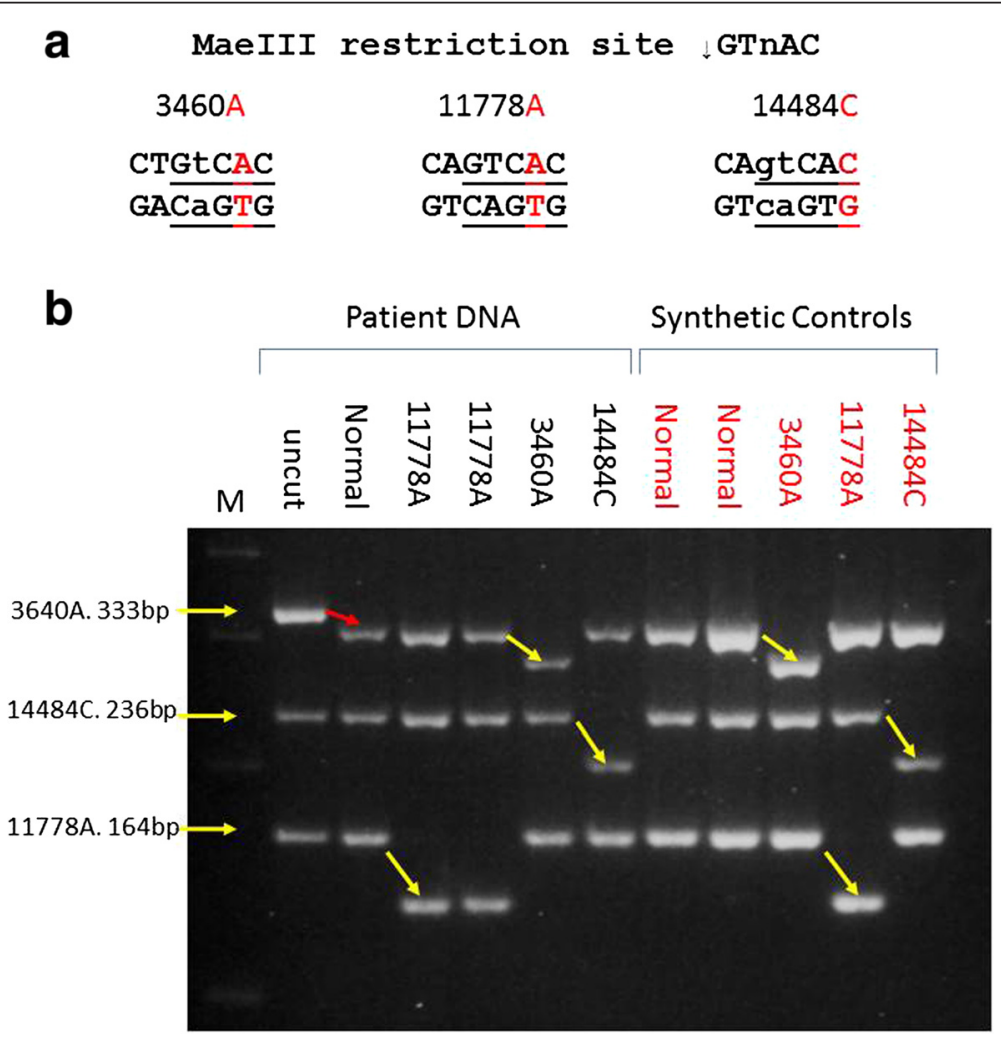

Fig. 2 Multiplex PCR-RFLP. a: Diagram demonstrating the introduction of Maell restriction sites by the mutation (11778A) and the combination of primer alterations and mutation (3460A, 14484C). Mutations are shown in red with the primer alterations in lower case. $\mathbf{b}: 2.5 \%$ ethidium bromide stained agarose gel showing the results of the PCR-RFLP on patient DNA (black labels) and synthesised DNA controls (red labels). DNA was PCR amplified in a multiplex reaction using $3460 \mathrm{~F} / \mathrm{R}, 11778 \mathrm{~F} / \mathrm{R}$ and $14484 \mathrm{~F} / \mathrm{R}$ and restricted using 1 unit of Maell as described. M: size marker; Uncut: non-restricted PCR products; All other lanes: patient (Black) or synthesised DNA controls (Red) containing the indicated mutation PCR amplified and restricted with Maell. The red arrow between the uncut and normal lanes demonstrates the internal control of restriction. Yellow arrows demonstrate mutation detection 


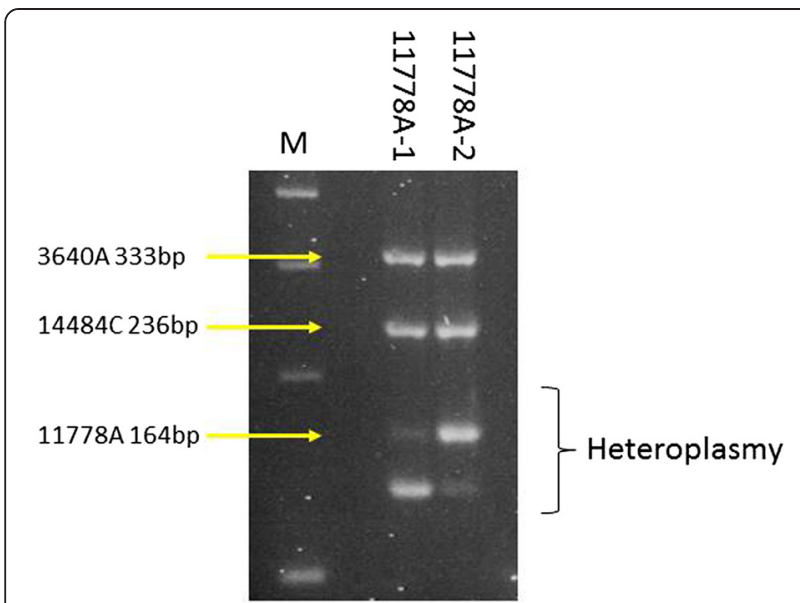

Fig. 3 Detection of heteroplasmy using multiplex PCR-RFLP. $2.5 \%$ ethidium bromide stained agarose gel showing the results of the multiplex PCR-RFLP on patient DNA heteroplasmic for G11778A mutation. M: size marker; 11778A-1: patient sample approximately $90 \%$ 11778A; 11778A-2: patient sample approximately $10 \%$ 11778A

G11778A (69 \%) and T14484C (14 \%). In approximately 110 diagnostic tests conducted in Ireland, only the 11778A mutation has been detected (data not shown). The PCR-RFLP approach was chosen because it provides a simple, cost effective, robust and easy to read output with minimal requirement for advanced technology. It also allows the detection of all three primary mutations in one multiplex analysis and allows the detection of heteroplasmy to a level of approximately $10 \%$. This is a significant advantage over individual endpoint PCR-RFLP [29] that requires 3 simplex PCRs followed by digestion with 3 separate restriction enzymes and electrophoresis. Allelespecific PCR [30], either simplex that requires 3 separate PCRs, or multiplex that requires only one PCR are efficient, but will not detect heteroplasmy in currently published formats. Individual real-time PCRs have been reported [31], but require more advanced technologies and are more costly. Individual endpoint PCR followed by bidirectional Sanger/pyrosequencing require significantly more hands-on time, and despite the decreasing costs of sequencing, are still significantly more expensive than the test reported here. As can been seen in Figs. $2 \mathrm{~b}$ and 3, mutation identification is clear and robust, both with patient DNA and with the synthesised controls described above.

The genetic testing registry (http://www.ncbi.nlm.nih. gov/gtr/) (accessed July 2015) shows that the vast majority of LHON testing involves uni- or bi-directional Sanger sequencing targeted to the 3 primary mutations $(n=20)$, targeted simplex PCR-RFLP $(n=8)$, and other testing methods (including real-time mutation detection, PCR followed by hybridisation and pyrosequencing) $(n=4)$ with 2 laboratories offering a targeted 37 mitochondrial gene Next generation sequencing (NGS) panel $\left(\mathrm{mtSEEK}^{\circ}\right)$.
PCR followed by Sanger/Pyrosequencing can be used for LHON mutation detection, but requires individual PCRs followed by individual sequencing reactions, and despite decreasing costs for sequencing, still costs significantly more than the test described in this study. NGS with appropriate panels, will detect the 3 primary mutations [33] but requires significantly more hands-on time for both set up and bioinformatics analysis and, at present, is unlikely to be used for the detection of known mutations due to the costs involved and the simplicity of alternative tests. NGS would, however, be invaluable in the detection of rarer / unknown mutations post initial screening for the 3 primary mutations and could be used for suspected LHON patients negative for the primary mutation screen. The assay reported in this study will allow diagnostic laboratories to avoid costly NGS assays for the vast majority of LHON patients and allow resources to be focussed on patients with unknown mutations requiring further analysis. We suggest that the test described in this study will allow detection of the 3 primary LHON mutations in a single test format at minimal cost, with a rapid turnaround time and without the need for advanced technology.

It is currently estimated that 35,000 individuals worldwide are vision-impaired due to LHON. With the addition of extended family members to this figure, there is a significant requirement for a simple cost-effective and robust diagnostic strategy for LHON mutation detection. The steps required to obtain approval for this diagnostic test for clinical applications include validation of the strategy in larger scale trials in multiple laboratories to ensure reproducibility and sensitivity/specificity followed by applications to the national and international competent authorities such as FDA and EU medical devices sections.

We also describe the generation of a series of controls for LHON applicable for all currently described LHON testing algorithms and demonstrate their applicability in this novel test. The generated controls have also been tested in simplex PCR-RFLP (as described in Marotta et al. 2004) and ARMS PCR (as described in $\mathrm{Bi}$ et al. 2010) - data not shown. The controls will provide an unlimited, reliable, and patient-free resource for LHON testing across all current testing platforms. This resource may allow the development of further tests in the future.

\section{Conclusion}

We developed a novel, cost-effective multiplex PCRRFLP based assay for the detection of the 3 most common mutations causing LHON and demonstrated the robustness of the assay in patient and synthetic controls. The assay provides a significant advantage over simplex PCR-RFLP and Sanger/pyrosequencing approaches to mutation detection in terms of costs 
and hands-on time required. A series of cloned LHON and normal controls were developed and their uses in this and other testing strategies confirmed. This will be a useful resource for future test development and diagnostic laboratories as it provides an unlimited and patient-free source of control material.

\section{Additional files}

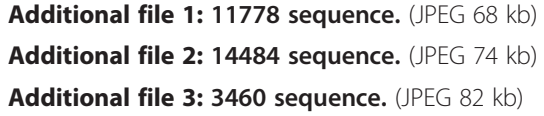

\section{Competing interests}

The authors declare that they have no competing interests.

\section{Authors' contributions}

SER carried out the molecular genetic studies, analysed results and drafted the manuscript. FR conceived the study, participated in its design and helped to draft the manuscript. DB contributed to the design of the experiments and critically reviewed the manuscript. VOD and DN supervised the work and helped to draft and critically review the manuscript. All authors read and approved the final manuscript.

\section{Acknowledgements}

We thank the Oxford Medical Genetics Laboratories, Oxford, UK for LHON patient samples. We thank Mr. B. Jennings FAOI from Fight for Sight Ireland and Mr. G. Meynet from the National Council for the Blind Ireland for helpful discussions on LHON. This study was supported by a grant from Fight for Sight to SER. SER is in receipt of a fee waiver from the Dublin Institute of Technology.

\section{Author details}

${ }^{1}$ National Optometry Centre, Dublin Institute of Technology, Kevin Street, Dublin 8, Ireland. ${ }^{2}$ School of Biological Sciences, Dublin Institute of Technology, Kevin Street, Dublin 8, Ireland. ${ }^{3}$ Centre for Medical Genetics, Our Lady's Hospital for Sick Children, Crumlin, Dublin 12, Ireland.

Received: 22 July 2015 Accepted: 6 October 2015

Published online: 25 October 2015

\section{References}

1. Leber T. Ueber hereditaere und congenital angelegte sehnervenleiden. Graefes Arch Ophthalmol. 1871;17:249-91.

2. Sadun AA, La Morgia C, Carelli V. Leber's Hereditary Optic Neuropathy. Curr Treat Options Neurol. 2011:13(1):109-17.

3. Wallace DC, Singh G, Lott MT, Hodge JA, Schurr TG, Lezza AM, et al. Mitochondrial DNA mutation associated with Leber's hereditary optic neuropathy. Science. 1988;242(4884):1427-30.

4. Man PY, Griffiths PG, Brown DT, Howell N, Turnbull DM, Chinnery PF. The epidemiology of Leber hereditary optic neuropathy in the North East of England. Am J Hum Genet. 2003;72(2):333-9.

5. Spruijt L, Kolbach DN, de Coo RF, Plomp AS, Bauer NJ, Smeets HJ, et al. Influence of mutation type on clinical expression of Leber hereditary optic neuropathy. Am J Ophthalmol. 2006;141(4):676-82.

6. Puomila A, Hamalainen P, Kivioja S, Savontaus ML, Koivumaki S, Huoponen K, et al. Epidemiology and penetrance of Leber hereditary optic neuropathy in Finland. Eur J Hum Genet. 2007;15(10):1079-89.

7. Howell N, Bindoff LA, McCullough DA, Kubacka I, Poulton J, Mackey D, et al. Leber hereditary optic neuropathy: identification of the same mitochondrial ND1 mutation in six pedigrees. Am J Hum Genet. 1991;49(5):939-50.

8. Johns DR, Neufeld MJ, Park RD. An ND-6 mitochondrial DNA mutation associated with Leber hereditary optic neuropathy. Biochem Biophys Res Commun. 1992:187(3):1551-7.

9. Howell N, Halvorson S, Burns J, McCullough DA, Paulton J. When does bilateral optic atrophy become Leber hereditary optic neuropathy? Am J Hum Genet. 1993;53(4):959-63.
10. Jun AS, Brown MD, Wallace DC. A mitochondrial DNA mutation at nucleotide pair 14459 of the NADH dehydrogenase subunit 6 gene associated with maternally inherited Leber hereditary optic neuropathy and dystonia. Proc Natl Acad Sci U S A. 1994;91(13):6206-10.

11. Howell N, Bogolin C, Jamieson R, Marenda DR, Mackey DA. mtDNA mutations that cause optic neuropathy: how do we know? Am J Hum Genet. 1998;62(1):196-202.

12. Chinnery PF, Brown DT, Andrews RM, Singh-Kler R, Riordan-Eva P, Lindley J, et al. The mitochondrial ND6 gene is a hot spot for mutations that cause Leber's hereditary optic neuropathy. Brain. 2001;124(Pt 1):209-18.

13. Wissinger B, Besch D, Baumann B, Fauser S, Christ-Adler M, Jurklies B, et al. Mutation analysis of the ND6 gene in patients with Lebers hereditary optic neuropathy. Biochem Biophys Res Commun. 1997;234(2):511-5.

14. De Vries DD, Went LN, Bruyn GW, Scholte HR, Hofstra RM, Bolhuis PA, et al. Genetic and biochemical impairment of mitochondrial complex I activity in a family with Leber hereditary optic neuropathy and hereditary spastic dystonia. Am J Hum Genet. 1996;58(4):703-11.

15. Liang M, Jiang P, Li F, Zhang J, Ji Y, He Y, et al. Frequency and spectrum of mitochondrial ND6 mutations in 1218 Han Chinese subjects with Leber's hereditary optic neuropathy. Invest Ophthalmol Vis Sci. 2014;55(3):1321-31.

16. Jiang $P$, Liang $M$, Zhang J, Gao $Y$, He Z, Yu H, et al. Prevalence of Mitochondrial ND4 Mutations in 1281 Han Chinese Subjects With Leber's Hereditary Optic Neuropathy. Invest Ophthalmol Vis Sci. 2015;56(8):4778-88.

17. DuBois LG, Feldon SE. Evidence for a metabolic trigger for Leber's hereditary optic neuropathy. A case report. J Clin Neuroophthalmol. 1992;12(1):15-6.

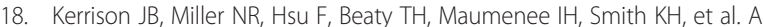
case-control study of tobacco and alcohol consumption in Leber hereditary optic neuropathy. Am J Ophthalmol. 2000;130(6):803-12.

19. Harding AE, Sweeney MG, Govan GG, Riordan-Eva P. Pedigree analysis in Leber hereditary optic neuropathy families with a pathogenic mtDNA mutation. Am J Hum Genet. 1995;57(1):77-86.

20. Tsao K, Aitken PA, Johns DR. Smoking as an aetiological factor in a pedigree with Leber's hereditary optic neuropathy. Br J Ophthalmol. 1999:83(5):577-81.

21. Johns DR, Smith KH, Miller NR, Sulewski ME, Bias WB. Identical twins who are discordant for Leber's hereditary optic neuropathy. Arch Ophthalmol. 1993;111(11):1491-4.

22. Yu-Wai-Man P, Griffiths PG, Hudson G, Chinnery PF. Inherited mitochondrial optic neuropathies. J Med Genet. 2009;46(3):145-58.

23. Dimitriadis K, Leonhardt M, Yu-Wai-Man P, Kirkman MA, Korsten A, De Coo IF, et al. Leber's hereditary optic neuropathy with late disease onset: clinical and molecular characteristics of 20 patients. Orphanet J Rare Dis. 2014;9:158.

24. Saadati HG, Hsu HY, Heller KB, Sadun AA. A histopathologic and morphometric differentiation of nerves in optic nerve hypoplasia and Leber hereditary optic neuropathy. Arch Ophthalmol. 1998;116(7):911-6.

25. Riordan-Eva P, Harding AE. Leber's hereditary optic neuropathy: the clinical relevance of different mitochondrial DNA mutations. J Med Genet 1995;32(2):81-7.

26. Newman NJ, Lott MT, Wallace DC. The clinical characteristics of pedigrees of Leber's hereditary optic neuropathy with the 11778 mutation. Am J Ophthalmol. 1991;111(6):750-62.

27. Johns DR, Smith KH, Miller NR. Leber's hereditary optic neuropathy. Clinical manifestations of the 3460 mutation. Arch Ophthalmol. 1992;1 10(11):1577-81.

28. Johns DR, Heher KL, Miller NR, Smith KH. Leber's hereditary optic neuropathy. Clinical manifestations of the 14484 mutation. Arch Ophthalmol. 1993;111(4):495-8.

29. Marotta R, Chin J, Quigley A, Katsabanis S, Kapsa R, Byrne E, et al. Diagnostic screening of mitochondrial DNA mutations in Australian adults 1990-2001. Intern Med J. 2004;34(1-2):10-9.

30. Bi R, Zhang AM, Yu D, Chen D, Yao YG. Screening the three LHON primary mutations in the general Chinese population by using an optimized multiplex allele-specific PCR. Clin Chim Acta. 2010:411(21-22):1671-4.

31. Wang JY, Gu YS, Wang J, Tong Y, Wang Y, Shao JB, et al. MGB probe assay for rapid detection of mtDNA11778 mutation in the Chinese LHON patients by real-time PCR. J Zhejiang Univ Sci B. 2008;9(8):610-5.

32. White HE, Durston VJ, Seller A, Fratter C, Harvey JF, Cross NC. Accurate detection and quantitation of heteroplasmic mitochondrial point mutations by pyrosequencing. Genet Test. 2005;9(3):190-9.

33. Tang S, Wang J, Zhang WW, Li FY, Landsverk M, Cui H, et al. Transition to next generation analysis of the whole mitochondrial genome: a summary of molecular defects. Hum Mutat. 2013;34(6):882-93. 